\title{
Correction to: Generalization of a theorem of Adegbindin, Luca and Togbé
}

\section{Djohra Meguedmi ${ }^{1} \cdot$ Salah Eddine Rihane ${ }^{2}$. Alain Togbé ${ }^{3} \mathbb{D}$}

Published online: 17 January 2022

(c) The Author(s) under exclusive licence to The Royal Academy of Sciences, Madrid 2022

\section{Correction to: RACSAM (2022) 116:36 https://doi.org/10.1007/s13398-021-01177-2}

The copyright holder for the article was incorrectly given as 'The Author(s), under exclusive licence to The Author(s) under exclusive licence to The Royal Academy of Sciences, Madrid' but should have been 'The Author(s) under exclusive licence to The Royal Academy of Sciences, Madrid'.

Publisher's Note Springer Nature remains neutral with regard to jurisdictional claims in published maps and institutional affiliations.

The original article can be found online at https://doi.org/10.1007/s13398-021-01177-2.

\footnotetext{
\ Alain Togbé atogbe@pnw.edu Djohra Meguedmi djohra.meguedmi@enst.dz

1 Ecole Nationale Supérieure de Technologie, Cité Diplomatique (Ex Centre Biomédical), Dergana, Bordj El Kiffan, 16000 Alger, Algérie

2 Department of Mathematics, Institute of Science and Technology, University Center of Mila, Mila, Algeria

3 Department of Mathematics, Statistics, and Computer Science, Purdue University Northwest, 1401 S, U.S. 421, Westville, IN 46391, USA
} 